UDC 902/904 (574); IRSTI 03.41.91

https://doi.org/10.47526/habarshy.vi1.374

\author{
K. ZHETIBAYEV ${ }^{1}$, B. SYZDYKOV ${ }^{2}$, M. BAKHTYBAYEV ${ }^{3}$, M. GURSOY ${ }^{2 *}$ \\ ${ }^{1}$ Candidate of Historical Sciences, Professor of Khoja Akhmet Yassawi International \\ Kazakh-Turkish University, Archaeology Research Institute \\ (Kazakhstan,Turkistan),e-mail: kopzhasar.zhetibayev@ayu.edu.kz \\ ${ }^{2} \mathrm{PhD}$, Senior Researcher at the Archaeology Research Institute \\ Khoja Akhmet Yassawi International Kazakh-Turkish University \\ (Kazakhstan,Turkistan),e-mails: muzaffer.gursoy@ayu.edu.kz; sizdikov.bagdaulet@ayu.edu.kz \\ ${ }^{3}$ Senior Researcher at the Archaeology Research Institute \\ Khoja Ahmet Yassawi International Kazakh-Turkish University \\ (Kazakhstan,Turkistan),e-mail: mels.bakhtybayev@ayu.edu.kz
}

\title{
EXPLORATION OF THE EASTERN GATE AND FORTRESS WALLS OF THE MEDIEVAL CITY OF SYGANAK
}

The article, based on medieval historical sources and research conducted on the medieval city of Sygnak, provides a brief overview of the role and significance of the city in the history of the Kazakh nation. One of the major centers on the Great Silk Road, the most important city on the Syr Darya, Sygnak has long been a well-developed culture, economy, crafts and trade, agriculture and cattle breeding.In the XI-XIII centuries it was known as one of the centers of the Kypchak Khanate, in the XIV-XV centuries it was the capital of Ak Orda, and in the XV-XVI centuries it was the capital of the Kazakh Khanate, becoming the political and economic center of the khanate. The defensive system of the medieval city of Sygnak, including the fortified walls with gates, has not been sufficiently studied, therefore, within the framework of this topic, we decided to conduct research work, identify the specifics of the city's defensive system and introduce it into scientific circulation.

The article examines the results of archaeological research carried out at the medieval settlement of Syganak, analyzes the architectural features of the eastern gates and fortress walls of the city, manufacturing technology and building materials. In addition, a comparative analysis of the Signak gate with the gates of medieval cities in the region was carried out and additional scientific conclusions were drawn. Based on field data obtained during the excavations, the chronology of the eastern gate and fortress walls was determined.

Keywords: city Syganak, gate, castle, Syrdarya, middle ages, medieval cities.

\footnotetext{
"Бізге дұрыс сілтеме жасацыз:

Zhetibayev K., Syzdykov B., Bahtybayev M., Gursoy M. Exploration of the Eastern Gate and Fortress Walls of the Medieval City of Syganak // Ясауи университетінің хабаршысы. - 2021. - №1 (119). - Б. 30-40. https://doi.org/10.47526/habarshy.vi1.374

Cite us correctly:

Zhetibayev K., Syzdykov B., Bahtybayev M., Gursoy M. Exploration of the Eastern Gate and Fortress Walls of the Medieval City of Syganak // Iasaýl ýnuversitetinin habarshysy. - 2021. - №1 (119). - B. 30-40. https://doi.org/10.47526/habarshy.vi1.374
} 


\author{
К. Жетібаев ${ }^{1}$, Б. Сиздиков ${ }^{2}$, М. Бахтыбаев ${ }^{3}$, М. Гурсой ${ }^{2}$ \\ ${ }^{1}$ тарих вылымдарының кандидаты, Қожа Ахмет Ясауи атындавы Халықаралық қуазақ-түрік \\ университетінің профессоры, Археология вылыми-зерттеу институть \\ (Қазақсстан, Түркістан к̧.), e-mail: kopzhasar.zhetibayev@ayu.edu.kz \\ ${ }^{2} \mathrm{PhD}$, Қожа Ахмет Ясауи атындавы Халықаралық қазақ̆-түрік университеті \\ Археология выльыми-зерттеу институтының ава вылыми қуызметкері \\ (Қазақ̧стан, Түркістан қ.), е-mails: muzaffer.gursoy@ayu.edu.kz; sizdikov.bagdaulet@ayu.edu.kz \\ ${ }^{3}$ Қожа Ахмет Ясауи атындавы Хальққаральқ құазақ--түрік университеті \\ Археология вылыми-зерттеу институтының ага гыльими қыззеткері \\ (Қазақ̧стан, Түркістан қ..), е-mail: mels.bakhtybayev@ayu.edu.kz
}

\title{
Ортағасырлық Сығанақ қаласының шығыс қақпасы мен қамал қабырғаларының зерттелуі
}

Мақалада Сығанақ қаласында жүргізілген зерттеулерді және ортағасырлық тарихи деректерді топтастыра отырып, қаланың қазақ халқының өткен тарихында алар орны мен маңызына қысқаша шолу жасалады. Ұлы Жібек жолы бойындағы ортағасырлық ірі орталықтардың бірі болған Сығанақ қаласы, ерте заманнан-ақ мәдениеті мен экономикасы, қолөнері мен саудасы, егіншілігі мен мал шаруашылығы қатар дамыған Сыр бойындағы маңызды қалалардың бірі болды. XI-XIII ғасырлар аралығында Қыпшақ хандығының басты орталықтарының бірі ретінде танылса, XIV-XV ғасырларда Ақ Орданың астанасы, ал XVXVI ғасырларда Қазақ хандығының астанасы болып, хандықтың саяси және экономикалық орталығына айналды. Ортағасырлық Сығанақ қаласының қорғаныс жүйесі, соның ішінде қақпасы мен қамал қабырғаларының аз зерттелуіне байланысты, аталмыш тақырып аясында ғылыми-зерттеу жұмыстарын жүргізіп, қаланың қорғаныс жүйесінің өзіндік ерекшелігін анықтап, ғылыми айналымға енгізуді жөн санадық. Мақалада Сығанақ қаласында жүргізілген археологиялық ғылыми-зерттеу жұмыстарының нәтижелеріне тоқтала отырып, қаланың шығыс қақпасы мен қамал қабырғаларының архитектуралық ерекшелігіне, жасалу технологиясы мен құрылыс материалдарына талдау жасалынды. Сонымен қатар, аймақтағы ортағасырлық қалалардың қақпаларымен салыстырмалы талдау жасалынып, қосымша ғылыми тұжырымдар айтылды. Қазба жұмысы барысында алынған заттай деректер негізінде қаланың шығыс қақпасы мен қамал қабырғаларының мерзімі анықталды.

Кілт сөздер: Сығанақ қаласы, қақпа, қамал, Сырдария, ортағасыр, ортағасырлық қалалар.

\section{К. Жетибаев ${ }^{1}$, Б. Сиздиков ${ }^{2}$, М. Бахтыбаев ${ }^{3}$, М.Гурсой ${ }^{2}$}

${ }^{1}$ кандидат исторических наук, профессор Международного казахско-туреиякого университета имени Ходжи Ахмеда Ясави, Научно-исследовательский институт археологии

Международного казахско-туреикого университета

(Казахстан, г. Туркестан), e-mail: kopzhasar.zhetibayev@ayu.edu.kz

${ }^{2} P h D$ доктор, старший научный сотрудник Научно-исследовательского института археологии Международного казахско-туреикого университета имени Ходжи Ахмеда Ясави

(Казахстан, г.Туркестан),e-mails: muzaffer.gursoy@ayu.edu.kz; sizdikov.bagdaulet@ayu.edu.kz

${ }^{3}$ старший научный сотрудник Научно-исследовательского института археологии Международного казахско-туреикого университета имени Ходжи Ахмеда Ясави

(Казахстан, г. Туркестан), e-mail: mels.bakhtybayev@ayu.edu.kz

\section{Исследование восточных ворот и крепостных стен средневекового города Сыганак}

В статье на основе средневековых исторических источников и исследований, проведенных на средневековом городе Сыганак дан краткий обзор роли и значения города в истории казахского народа. Сыганак - один из крупных центров на Великом Шелковом 
пути, важнейший город на Сырдарье. Издавна в Сыганаке была хорошо развита культура, экономика, ремесло и торговля, земледелие и скотоводство. В XI-XIII веках был известен как один из центров Кыпчакского ханства, в XIV-XV веках - был столицей Ак Орды, а в XV-XVI веках - столицей Казахского ханства, став политическим и экономическим центром ханства. Оборонительная система средневекового города Сыганак, в том числе крепостные стены с воротами, недостаточно изучена, поэтому в рамках данной темы мы решили провести научно-исследовательскую работу, выявить специфику оборонительной системы города и ввести ее в научный оборот. В статье рассмотрены результаты археологических исследований, проведенных на средневековом городище Сыганак, проанализированы архитектурные особенности восточных ворот и крепостных стен города, технология изготовления и строительные материалы. Кроме того, был проведен сравнительный анализ сыганакских ворот с воротами средневековых городов региона и сделаны дополнительные научные выводы. На основании натурных данных, полученных в ходе раскопок, была определена хронология восточных ворот и крепостных стен.

Ключевые слова: город Сыганак, ворота, замок, Сырдарья, средневековье, средневековые города.

\section{Introduction}

Syganak, one of the largest medieval cities of the Great Silk Road, is located $2 \mathrm{~km}$ away in the north-west direction from Sunakataaul, Zhanakorgan district, Kyzylorda region. Syganak has a special place in the history of the Kazakh people, as well as the Turkic peoples, since the city was the capital of the Kipchak Khanate (XI-XIII centuries), the White Horde (XIV-XV centuries) and the Kazakh Khanate (XV-XVI centuries) [1, p. 3].

According to the studies of the first Russian scientists, Syganak began to attract attention in the second half of the 19th century. For the first time in 1867, on behalf of the Russian Archaeological Commission, the archaeologist P.I. Lerha was sent to explore the medieval cities of Turkestan region. The scientist visited the city and provided information about its location and preservation at that time [2, p. 38]. In 1892, during geological exploration from Tashkent to Kyzylorda, local historian E.A. Smirnov visited the city of Syganak and described its territory, Tyumenaryk and the city's irrigation system. Unfortunately, there is no information about the city [3, p. 7]. Also, in 1899 the head of the local history department of Turkestan V.A. Kallaur explored the city, and described its topography, in addition drew the project of mosque, which is 100 meters away from the eastern gate of the city. Furthermore, the scientist informed that the medieval city of Syganak was surrounded by walls, and the domes of a red brick mosque had been partially preserved [4]. In 1906, archaeologist I.A. Castan conducted research, and complemented the description of the city by Kallaur [5, pp. 189-192].

In 1927, on behalf of the Institute of Material Culture, A.Y. Yakubovsky explored the city Syganak. He paid special attention to the topography of the city, photographed and described the preserved monuments near the city. In addition, scientist collected information about the city and published a scientific article [6].

In 1947, the head of the South Kazakhstan archaeological expedition A.A. Bernshtam visited the site of the monument, drew up a topographic project of the city and found out that the city had been existing since the time of the Kangli based on collected materials [7, p. 59-99]. Furthermore, members of the South Kazakhstan archaeological expedition E.I. Ageeva and G.I. Patsevichi carried out excavations, and on the basis of the collected materials, discovered that the city lived in the $\mathrm{V}$ VIII centuries, recovered in the XII-XVI centuries after falling and revived during the White Horde [8, pp. 206-208]. However, the aforementioned scientists did not conduct any archaeological excavations in the city, but only explored and described the city and its surroundings. Also, they tried to determine the period of the city's existence by collecting materials about the city. 
In the $70 \mathrm{~s}$ of the twentieth century, the head of the Otyrar archaeological expedition K.A. Akishev and K. Baipakov studied the city topographically and identified it as the second most famous medieval city after Otyrar [9].

Nevertheless, none of the above-mentioned scientists conducted archeological excavations in the city. As a result, the city was neglected by scientists and became a cemetery until year 2000 . The archeological condition of the city is very poor. Archaeologists from the International KazakhTurkish University named after Hodja Ahmet Yasawi have been conducting archeological excavations in the city since 2003. Owing to archeological excavations carried out in past years, the eastern gate of the city, the walls of the fortress near the gate, living quarters, the central mosque and the mausoleums in the city were opened and put into scientific circulation. In addition, stratigraphic sections were built in two parts of the city and the chronology of the cultural layers of the city was determined [18, pp. 77-78].

\section{Study of the eastern gate and walls of the city of Syganak}

The Research Institute of Archaeology of the International Kazakh-Turkish University named after Hodja Ahmet Yasawi conducted archeological excavations in 2011 in the area marked as the site of the eastern corner of Syganak in order to identify the eastern gate of the medieval city of Syganak. This is located in the eastern corner of the medieval city of Syganak. The topographic design of the gate clearly shows the peculiarities of construction. The area, marked as a gate, protrudes 35-40 m from the city walls. On both sides of the gate, the walls are attached to the main fortress that surrounds the city. On either side of the gate, there are two additional towers for gatekeepers or archers against perpetrators of the wall during the war. In the inner part of the gate structure, there is a main street facing northwest. On the outside of the gate, there are traces of the pit that surrounds the entire city. The excavation site is conventionally designated as No. 9. The site of the eastern gate, which is the main gate of the city, was cleared from very dense haloxylon, birch, wormwood and etc. It adjoins the main fortress surrounding the city and stretches about $35-40 \mathrm{~m}$ to the east. Excavations were carried out to determine the design of the gate on the basis of construction sites indicated in the topographic project (Fig. 1) [10, p. 77-92].

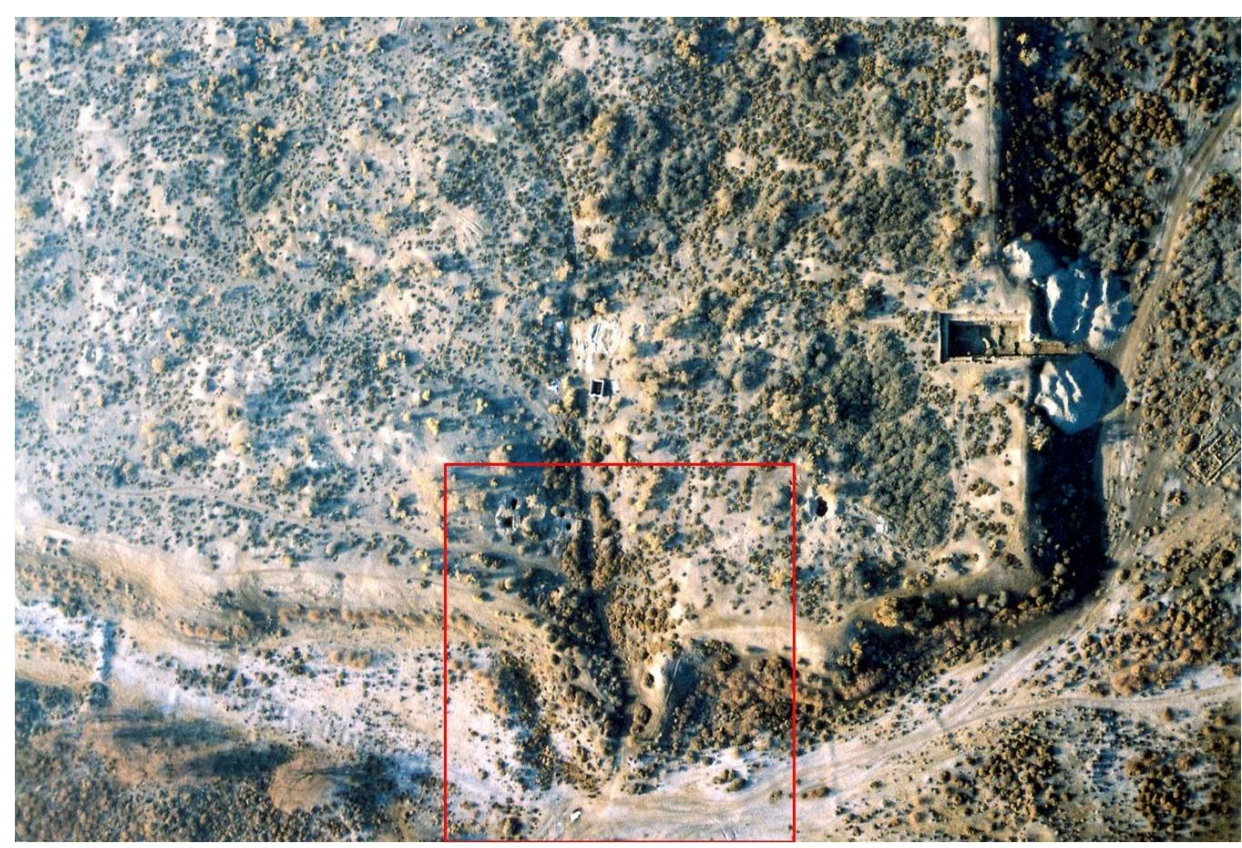

Figure 1 - View to the excavation of the eastern gate of Syganak 
Excavations at the eastern gate of the medieval city of Syganak from 2011 to 2013 revealed that the gate was oriented to the south-east, in front of the gate there was a horde surrounding the city, a suspension bridge on ceramic platforms and two towers with an area of $4 \mathrm{~m}$ on the right and left sides. Also, the places of the gate pedestal, the floor with burnt pottery fragments, the walls of the fortress and two rows of brick walls were identified [10, pp. 77-92; 11; 12, pp. 14-26]. However, the gate is poorly preserved. This was due, firstly, to the thick vegetation layer, which negatively affected the preservation of the building floor. Secondly, during the Soviet era, the water from the rice fields around the monument was collected around the city, and thirdly, before the excavation in 2009 , the villagers entered the city center.

During the excavation, ceramic protective openings were identified on the right side of the ceramic wall, which was attached to the gate from the inside of the gate. Based on the architectural structure of the gate and the location of the defensive openings, we conclude that it may be the inner gate of the city. This is due to the fact that the walls of the gates on both sides of the gate are bent and attached to the towers, and the mouths of the above-mentioned protective openings open inwards. The curved position of the wings prevents the movement of intruders and may have protected the inner gate by resisting the enemy through the above-mentioned protective openings. This is because these openings are directed inwards, not outwards. For these reasons, we conclude that there may be a second gate inside the eastern gate of the medieval city of Syganak (Figure 2).

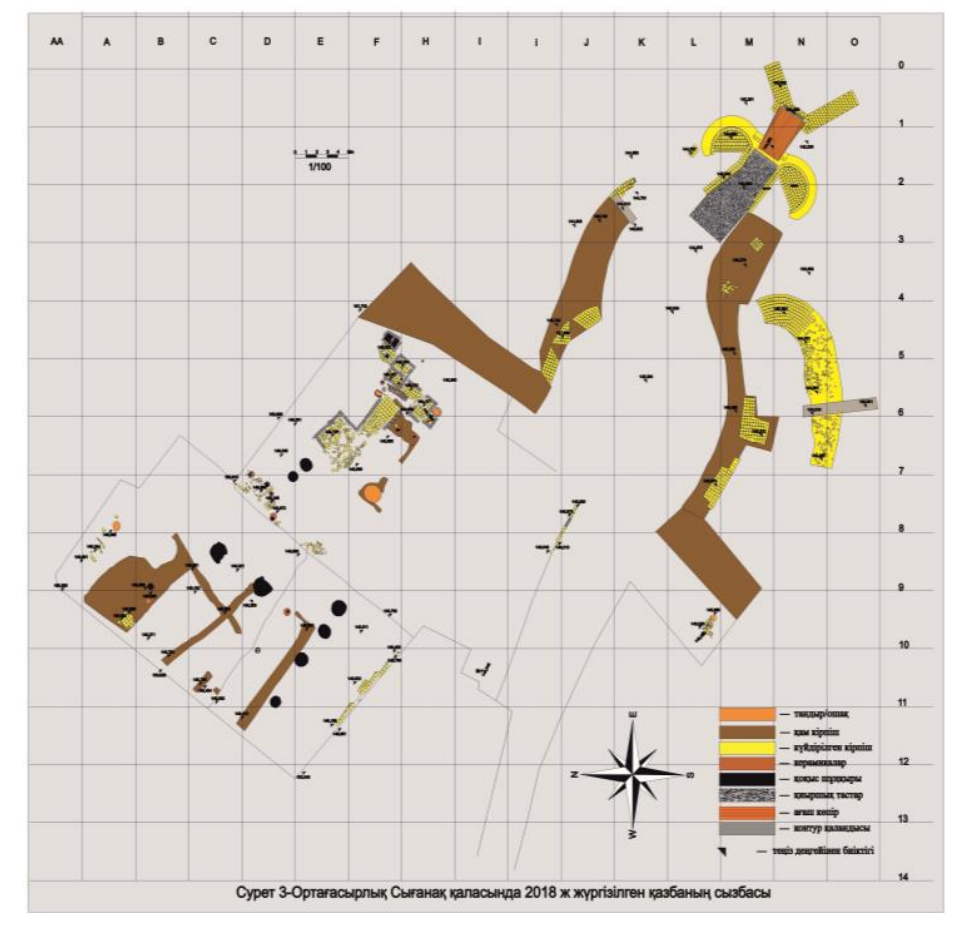

Figure 2 - Project of the eastern gate of Syganak

Archaeological excavations of medieval monuments have revealed medieval cities with internal and external gates. The city of Otyrar is one of the medieval cities with internal and external gates. The location of the second gate was determined from the inside of the southern gate, which is the main gate of Otyrar (Figure 3). The walls in front of the inner gate are right angled [13, pp. 413-430]. That is, the front of the inner gate is narrow. The narrowness of the front of the gate impedes the movement of intruders and allows protecting the inner gate by resisting the enemy through the protective openings on both sides. 


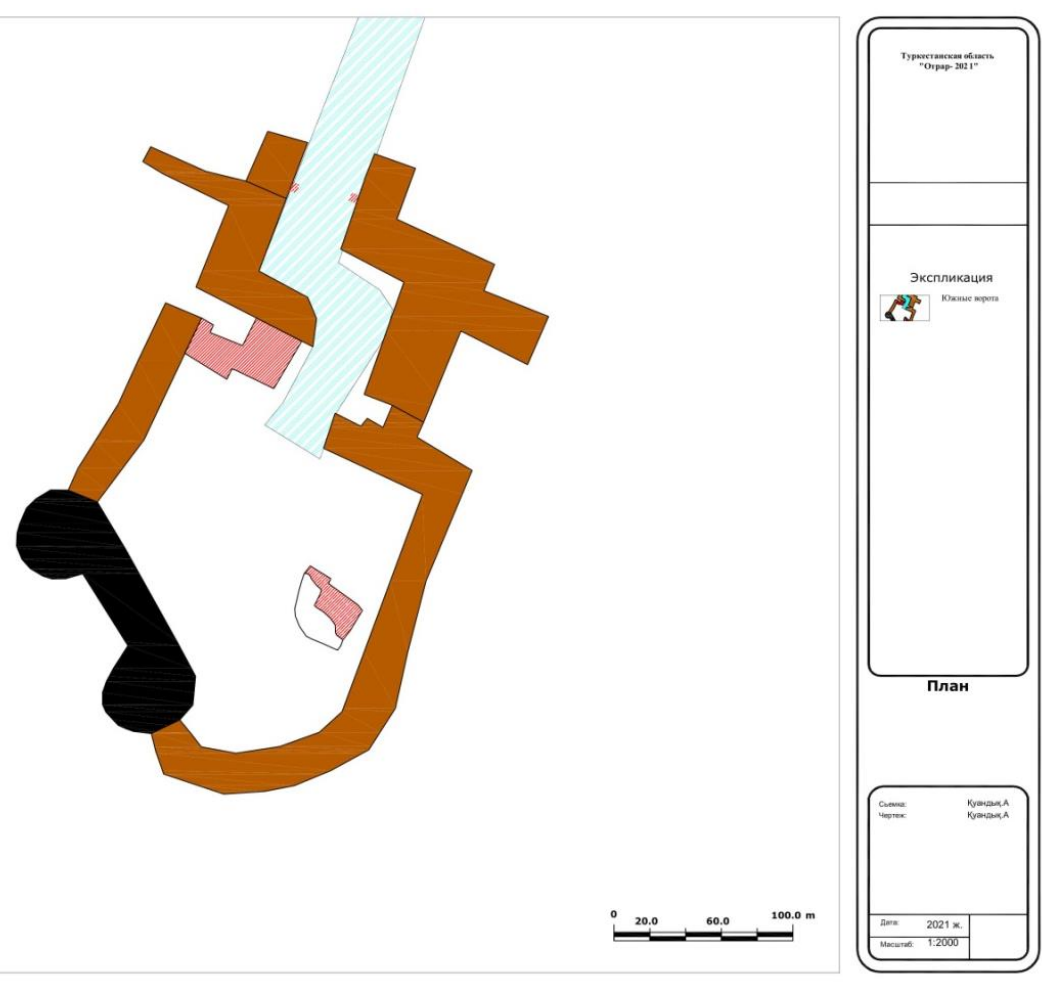

Figure 3 - Project of the eastern gate of Otyrar

Excavations in the town of Syganak revealed the location of a ceramic tower and rooms for gatekeepers protruding from the left side of the ceramic wall attached to the gate from the inside of the gate [19, pp. 7-17]. Rooms for guards inside the gates were also discovered during excavations in the medieval Sauran and Otrar (Figure 4) [14, pp. 8-26]. These rooms are small and located close to or adjacent to the tower.

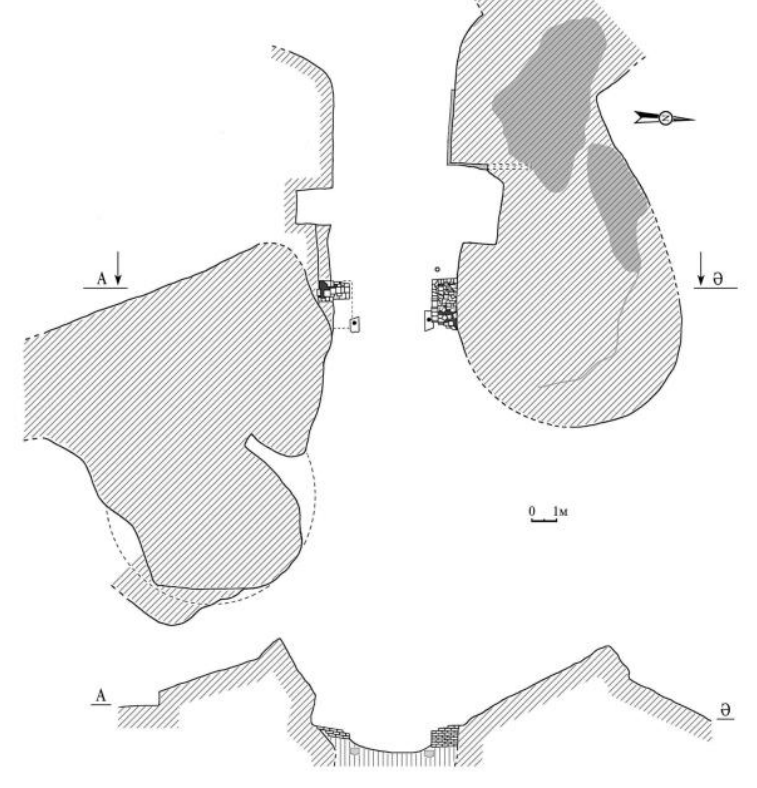

Figure 4 - Project of the eastern gate of Sauran 
In the construction of the gates of the medieval city of Syganak, pieces, baked ceramics, stone, wood and decorative ceramics of the surrounding mausoleums of the XII-XIV centuries were used. The sizes of ceramics used in the construction of the gates are various: $27 \times 27 \times 5,26 \times 26 \times 5$, $23 \times 23 \times 5 \mathrm{~cm}$.

The gate of the medieval city of Syganak is a building with its own architectural features. This gate differs from the gates of Sauran and Otyrar in this region. Unfortunately, no special excavations were carried out on the gates of many medieval cities. For example, the construction of the tower of the gates of Otyrar was built protruding from the city platform, and this feature can be seen to some extent in the construction of the gates of Sauran. There is also a suspension bridge in front of both city gates. The pier for the suspension bridge in front of the gates of Syganak has not been identified yet. However, it may be determined as a result of large-scale excavations in the future. The main platform of Syganak is made of fired brick, the front two side towers are made of fired brick and the main platform is protruding $4.5 \mathrm{~m}$ forward. The highest point of the platform is $1.7 \mathrm{~m}$ and continues downwards; however, it was not fully opened due to groundwater leakage during the excavation. Unlike the gates of the medieval cities of Sauran and Otrar, where the main gates of Syganak were excavated, there is an additional tower inside the gate for the gatekeepers. The tower is located on the left side of the inner part of the gate. The tower was discovered during excavations in 2018. Chief Architect of the Republican State Institution "Kazreconstruction" $\mathrm{N}$. Imazhanov, who is carrying out the reconstruction of facilities in the city of Syganak, suggests that the second tower should be on the right side of the gate. N. Imazhanov, based on the defense system of the city and the architectural features of the gate, concludes that there should be a second additional tower for the protection of the gate.

As for the chronology of the gate, archeological data obtained during the excavations allow to determine the date of construction of the gate. During archeological excavations at the site of the gate, several copper coins of the XIV-XVI centuries and fragments of decorative ceramic casings of the XII-XIV centuries were found. Among the found copper coins are coins of the 14th century with the inscription "Sarai al-Jadid" and fels of the XV-XVI centuries. During the excavation, a large number of fragments of decorative ceramics of the XII-XIV centuries, painted in different sizes and with different ornaments, were found between the ruins of the burnt brick platform at the entrance to the gate and the tower. We believe that the ceramic tiles were brought from medieval buildings (mausoleums) around the city and used for the construction of gates. This is due to the fact that these decorative ceramic tiles are found among the ceramic tiles in the form of broken particles.

The walls of the fortress on the right and left sides of the eastern gate of the medieval city of Syganak were discovered during archeological excavations in 2019-2020. In order to open the outer parts of the fortress walls on the left and right sides of the city gates, cleaning works were carried out and reconnaissance sections with a width of $2 \mathrm{~m}$ were built. During the excavations, fragments of ceramics dating back to the XVII-XVIII centuries, fragments of pottery and a large number of cut-out saiga horns were found in the upper part of the walls of the fortress. The outside of the fortress wall was completely cleared of loose soil. It was found that the wall was built on a platform made of black and yellow clay. The wall is oriented from south-west to north-east, it is made of bricks measuring $12 \times 20 \times 40 \mathrm{~cm}$. In the middle of the ridge, at a height of $1 \mathrm{~m}$ above the level of the footing, $0.5 \mathrm{~cm}$ thick reeds were laid, and the lower layers were made of yellow clay. The size of the identified pieces was 42x27x12 cm. The pieces are made of light orange clay (Figure 5) [15, pp. 7-21]. 

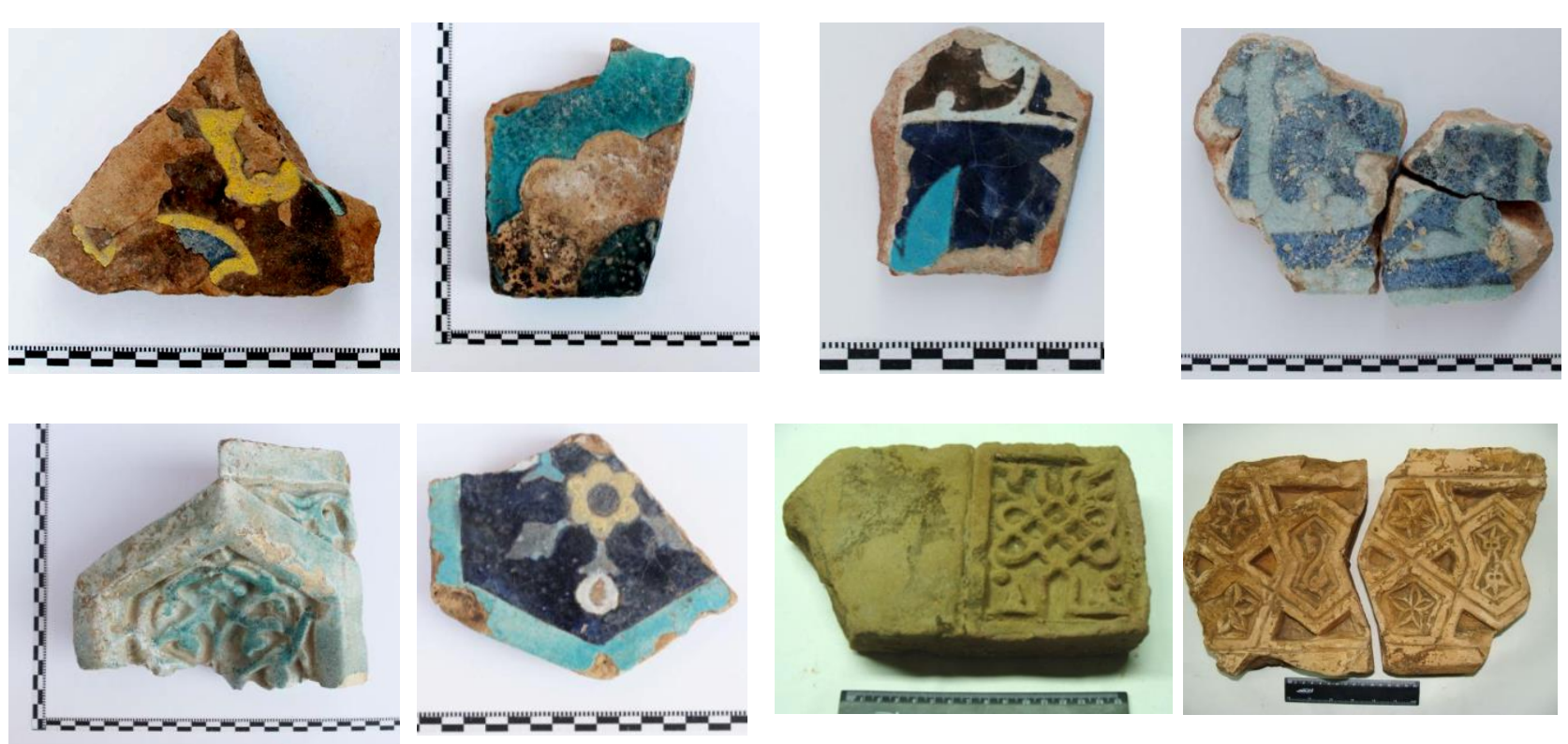

Figure 5 - Finishing ceramic tiles from the eastern gate of Syganak

The left wall of the fortress was opened at a length of $50 \mathrm{~m}$ and a height of $2.5 \mathrm{~m}$. As a result, it was found that the walls were made of bricks measuring $12 \times 20 \times 40 \mathrm{~cm}$. The right wall was $30 \mathrm{~m}$ long and 2.5-3 m high. Also, in this part, the outside of the tower of the fortress wall was opened, and the outer area was found to be $24 \mathrm{~m}$ wide and 2-4 m high. As a result of archeological excavations, the Kyzylorda branch of RSE "Kazreconstruction" of Kyzylorda region carried out restoration work on the identified eastern gate, fortress wall and tower (Figure 6) [16, pp. 16-17; 17, pp. 312-325].

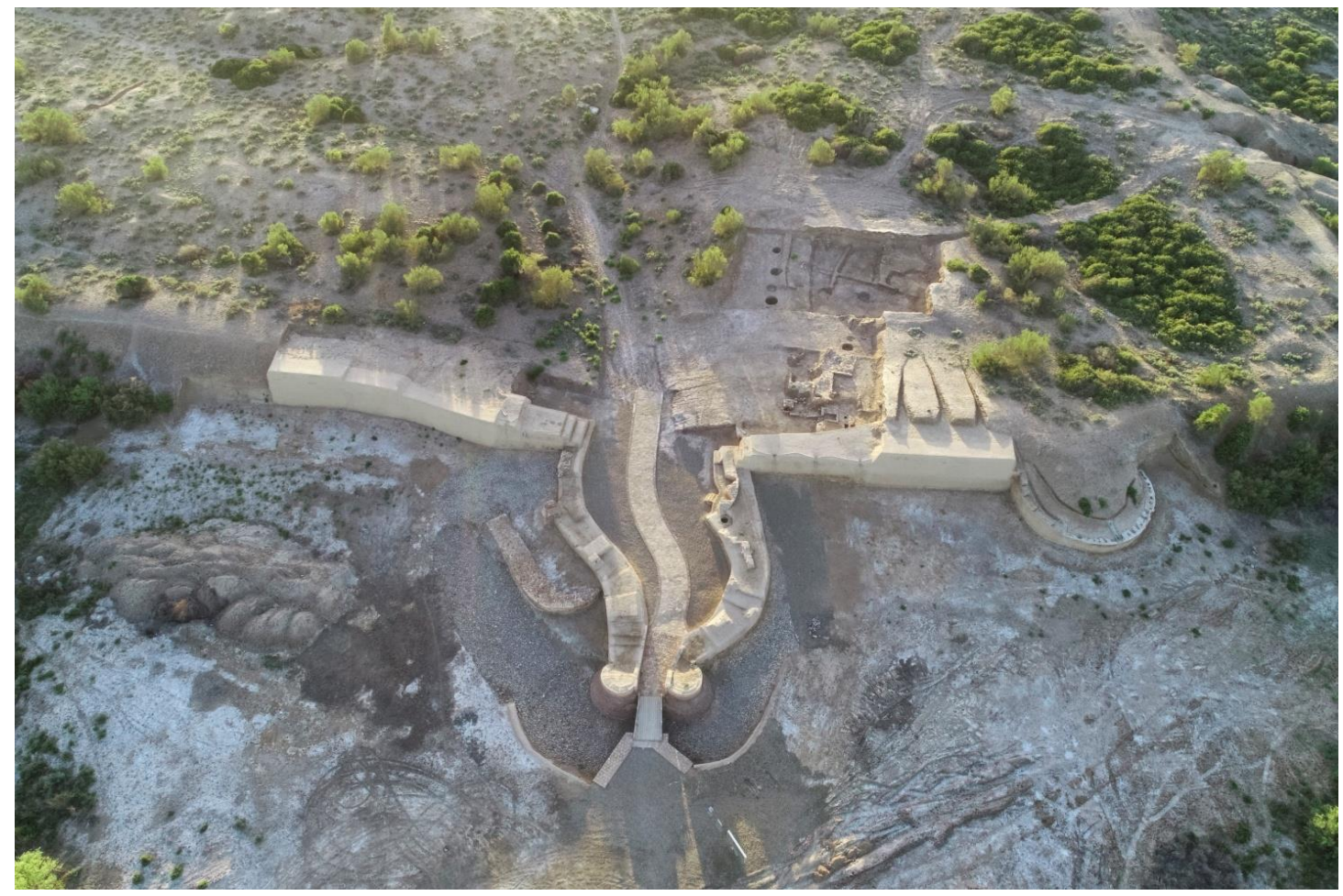

Figure 6 - Aerial view of the eastern gate of Syganak 


\section{Conclusion}

The eastern gate of the medieval city of Syganak is a building with its own architectural features. Unfortunately, due to the lack of special excavations at the gates of many medieval cities in the region, it was not possible to identify specific specimens. A comparative analysis of the Syganak Gate with the main gates of the medieval cities of Sauran and Otyrar in the region revealed similarities and differences in the structure of the gates. The location of suspension bridges at the gates of these cities, the location of guard rooms inside the gates and the fact that the structure of the inner part is in the form of narrow intersections show similarities. The eastern gate of Syganak differs from the gates of the medieval cities of Sauran and Otyrar in that there is an additional tower inside the gate for the gatekeepers and the main platform is protruding $4.5 \mathrm{~m}$. In addition, the location of the ceramic protective recesses on the right side of the ceramic wall, which is planned to be built from the inside of the gate to the gate, distinguishes this gate from the above-mentioned gates.

As for the chronology of the gate, based on archeological data obtained during the excavations, we determined the time of construction of the gate. Archaeological excavations at the site of the gate revealed that the eastern gate dates back to the XIV-XVI centuries, based on several copper coins dating back to the XIV-XVI centuries. Among the found copper coins there are 14thcentury's coins with the inscription "Sarai al-Jadid" and the fels of the $15^{\text {th }}-16$ th centuries, which have not been preserved.

\section{BIBLIOGRAPHY}

1. Жолдасбаев С. Ортағасырлық Сығанақ қаласы (X-XVIII ғғ.). - Түркістан: Тұран баспасы, 2009. - 246 б.

2. Лерх П. Археологическая поездка в Туркестанский край в 1867 году. - СПб.: Типография императ. акад. наук, 1870. - 38 с.

3. Смирнов Е.А. Древности на среднем и нижнем течении р. Сырдарьи // ПТКЛА от 17 февраля 1897. - 7 с.

4. Каллаур В.А. Древние города Саганак (Сунак), Ашнас или Эшнас (Асанас) в Перовском уезде, разрушенные Чингиз-ханом 1219 г. / ПТКЛА. Приложения к протоколу от 7 февраля 1900.

5. Кастанье И.А. Надгробные сооружения киргизских степей. - Оренбург, 1911. - С. 189192 .

6. Якубовский А.Ю. Развалины Сыгнака / Сообщения ГАИМК. 1929.

7. Бернштам А.Н. Проблемы древней истории и этногенеза Южного Казахстана / Известия АН Каз ССР. Серия археологическая. Выпуск 2. - Алматы, 1949. - С. 59-99.

8. Агеева Е.И., Пацевич Г.И. Из истории оседлых поселений и городов Южного Казахстана / Труды ИИАЭ АН Каз ССР. Т.5. - Алматы, 1958. - 215 с.

9. Акишев К.А., Байпаков К.М., Ерзакович Л.Б. Древний Отрар. - Алматы, 1970. - 207 с.

10. Жолдасбаев С., Мургабаев С., Бахтыбаев М., Нурханов Б., Арынов Қ. 2011 жылы Ортағасырлық Сығанақ қаласында жүргізілген ғылыми-зерттеу жұмыстарының есебі. Түркістан, 2011. - 133 б.

11. Жолдасбаев С., Мургабаев С., Бахтыбаев М., Нурханов Б., Арынов Қ. 2012 жылы Ортағасырлық Сығанақ қаласында жүргізілген ғылыми-зерттеу жұмыстарының есебі. Түркістан, 2012. - 145 б.

12. Жолдасбаев С., Мургабаев С., Бахтыбаев М., Нурханов Б., Арынов Қ. 2013 жылы Ортағасырлық Сығанақ қаласында жүргізілген ғылыми-зерттеу жұмыстарының есебі. Түркістан, 2013. - 49 б.

13. Акылбек С.Ш. Цитадели Отрара / Археологияның шыңына шыққан К.А. Ақышевтың туғанына 90 жыл толуына арналған «Қазақстан территориясындағы ежелгі және 
ортағасырлық мемлекеттер» атты халықаралық ғылыми конференция материалдарының жинағы. - Алматы, 2014. - Б. 413-430.

14. Елеуов М., Ақымбек Е., Қалиев С,. Әлжанов Р. Тұран археологиялық экспедициясының 2005 жылы Республикалық «Мәдени мұра» бағдарламасы бойынша жасаған «Ортағасырлық Сауран қаласы» келісім шарт тақырыбында жүргізген зерттеулері. Түркістан, 2005. - Б. 8-26.

15. Жолдасбаев С., Жетібаев К., Бахтыбаев М., Мургабаев С., Арынов Қ., Сиздиков Б., Гурсой М., Амантуров М., Малдыбекова Л. «Қызылорда облысының мәдениет, мұрағаттар және құжаттама басқармасының Қызылорда облыстық тарихи және мәдени ескерткіштерді қорғау жөніндегі» коммуналдық мемлекеттік мекемесі тапсырысы бойынша орындалған «Қызылорда облысы, Жаңақорған ауданындағы Сығанақ қалашығына археологиялық зерттеу жұмыстарын жүргізу» тақырыбы бойынша 2019 жылы атқарылған ғылыми-зерттеу жұмыстары жайлы есеп. - Түркістан, 2020. - 118 б.

16. Жолдасбаев С., Жетібаев К., Бахтыбаев М., Мургабаев С., Арынов Қ., Сиздиков Б., Гурсой М., Амантуров М., Малдыбекова Л. «Қызылорда облысының мәдениет, мұрағаттар және құжаттама басқармасының Қызылорда облыстық тарихи және мәдени ескерткіштерді қорғау жөніндегі» коммуналдық мемлекеттік мекемесі тапсырысы бойынша орындалған «Қызылорда облысы, Жаңақорған ауданындағы Сығанақ қалашығына археологиялық зерттеу жұмыстарын жүргізу» тақырыбы бойынша 2019 жылы атқарылған ғылыми-зерттеу жұмыстары жайлы есеп. - Түркістан, 2019. - 161 б.

17. Жетібаев К., Жолдасбаев С., Арынов Қ., Бахтыбаев М. Сығанақ қалашығында 2019 жылы жүргізілген археологиялық зерттеу жұмыстарының нәтижелері // Ясауи университетінің хабаршысы. - 2020. - №2 (116). - Б. 312-325.

18. Zholdasbaev S., Aldabergenova M. The medival town of Kazakhstan // Asian Social Science. Volume 9, Issue 5, 2013. - P. 73-82.

19. Жолдасбаев С., Жетібаев К., Бахтыбаев М., Арынов Қ. Сығанақ қалашығының шығыс қақпасында жүргізілген археологиялық қазба жұмыстары // Ясауи университетінің хабаршысы. - 2019. - №1 (111). - Б. 7-17.

\section{REFERENCES}

1. Joldasbaev S. Ortaǵasyrlyq Syǵanaq qalasy (X-XVIII ǵǵ.). - Túrkistan: Turan baspasy, 2009. - 246 b. [in Kazakh].

2. Lerh P. Arheologicheska1a poezdka v Týrkestanskı1 kraı v 1867 godý. - SPb.: Tıpografi1a 1mperat. akad. naýk, 1870. - 38 b. [in Russian].

3. Smirnov E.A. Drevnostı na srednem 1 nijnem techenı1 r. Syrdarıa // PTKLA ot 17 fevralıa 1897. - 7 s. [in Russian].

4. Kallaýr V.A. Drevnıe goroda Saganak (Sýnak), Ashnas 1lı Eshnas (Asanas) v Perovskom ýezde, razrýshennye Chıngız-hanom 1219 g. // PTKLA. Prılojenı1a k protokolý ot 7 fevralıa 1900. [in Russian].

5. Kastane I.A. Nadgrobnye soorýjenı1a kırgızskıh stepeı. - Orenbýrg, 1911. - 189-192 b. [in Russian].

6. Iakýbovskı1 A.Iý. Razvalıny Sygnaka // Soobschenı1a GAIMK. - 1929. [in Russian].

7. Bernshtam A.N. Problemy drevne1 1stor11 1 etnogeneza Iýjnogo Kazahstana // Izvestı1a AN Kaz SSR. Serı1a arheologicheskaı. Vypýsk 2. - Almaty: Tıp. Týrg. obl. pravl., 1949. - 59-99 b. [in Russian].

8. Ageeva E.I., Patsevich G.I. Iz 1storı osedlyh poselen11 1 gorodov Iýjnogo Kazahstana // Trýdy IIAE AN Kaz SSR. T.5. - Almaty, 1958. - 215 b. [in Russian].

9. Akıshev K.A., Baipakov K.M., Erzakovıch L.B. Drevnıı Otrar. - Almaty: Naýka, 1970. 207 b. [in Russian]. 
10. Joldasbaev S., Mýrgabaev S., Bahtybaev M., Nýrhanov B., Arynov Q. 2011 jyly Ortaǵasyrlyq Syǵanaq qalasynda júrgizilgen ǵylymı-zertteý jumystarynyń esebi. - Túrkistan: Turan, 2011. 133 b. [in Kazakh].

11. Joldasbaev S., Mýrgabaev S., Bahtybaev M., Nýrhanov B., Arynov Q. 2012 jyly Ortaǵasyrlyq Syǵanaq qalasynda júrgizilgen ǵylymı-zertteý jumystarynyń esebi. - Túrkistan: Turan, 2012. 145 b. [in Kazakh].

12. Joldasbaev S., Mýrgabaev S., Bahtybaev M., Nýrhanov B., Arynov Q. 2013 jyly Ortaǵasyrlyq Syǵanaq qalasynda júrgizilgen ǵylymı-zertteý jumystarynyń esebi. - Túrkistan: Turan, 2013. 49 b. [in Kazakh].

13. Akylbek S.Sh. Tsitadelı Otrara / Arheologılanyń shyńyna shyqqan K.A. Aqyshevtyń týǵanyna 90 jyl tolýyna arnalǵan «Qazaqstan terrıtorıasyndaǵy ejelgi jáne ortaǵasyrlyq memleketter» atty halyqaralyq ǵylymı konferentsı materıaldarynyń jınaǵy. - Almaty, 2014. - B. 413-430. [in Kazakh].

14. Eleýov M., Aqymbek E., Qalıev S,. Áljanov R. Turan arheologialyq ekspeditsısynyń 2005 jyly Respýblıkalyq «Mádenı mura» baǵdarlamasy boıynsha jasaǵan «Ortaǵasyrlyq Saýran qalasy» kelisim shart taqyrybynda júrgizgen zertteýleri. - Túrkistan: Turan, 2005. - 8-26 b. [in Kazakh].

15. Joldasbaev S., Jetibaev K., Bahtybaev M., Mýrgabaev S., Arynov Q., Sizdıkov B., Gýrso1 M., Amantýrov M., Maldybekova L. «Qyzylorda oblysynyń mádenıet, muraǵattar jáne qujattama basqarmasynyń Qyzylorda oblystyq tarıhı jáne mádenı eskertkishterdi qorǵaý jónindegi» kommýnaldyq memlekettik mekemesi tapsyrysy bo1ynsha oryndalǵan «Qyzylorda oblysy, Jańaqorǵan aýdanyndaǵy Syǵanaq qalashyǵyna arheologılalyq zertteý jumystaryn júrgizý» taqyryby bo1ynsha 2019 jyly atqarylǵan ǵylymı-zertteý jumystary ja1ly esep. - Túrkistan: Turan, 2020. - 118 b. [in Kazakh].

16. Joldasbaev S., Jetibaev K., Bahtybaev M., Mýrgabaev S., Arynov Q., Sizdıkov B., Gýrso1 M., Amantýrov M., Maldybekova L. «Qyzylorda oblysynyń mádenıet, muraǵattar jáne qujattama basqarmasynyń Qyzylorda oblystyq tarıhı jáne mádenı eskertkishterdi qorǵaý jónindegi» kommýnaldyq memlekettik mekemesi tapsyrysy boiynsha oryndalǵan «Qyzylorda oblysy, Jańaqorǵan aýdanyndaǵy Syǵanaq qalashyǵyna arheologılalyq zertteý jumystaryn júrgizý» taqyryby boıynsha 2019 jyly atqarylǵan ǵylymı-zertteý jumystary ja1ly esep. - Túrkistan: Turan, 2019. - 161 b. [in Kazakh].

17. Jetibaev K., Joldasbaev S., Arynov Q., Bahtybaev M. Syǵanaq qalashyǵynda 2019 jyly júrgizilgen arheologilalyq zertteý jumystarynyń nátijeleri // Iasaý1 ýnıversıtetiniń habarshysy. 2020. - №2 (116). - B. 312-325. [in Kazakh].

18. Zholdasbaev S., Aldabergenova M. The medival town of Kazakhstan // Asian Social Science. Volume 9, Issue 5, 2013. - P. 73-82.

19. Joldasbaev S., Jetibaev K., Bahtybaev M., Arynov Q. Syǵanaq qalashyǵynyń shyǵys qaqpasynda júrgizilgen arheologilalyq qazba jumystary // Iasaý1 ýnıversıtetiniń habarshysy. 2019. - №1 (111). - B. 7-17. [in Kazakh]. 